$\mathrm{A} \int_{\cos } \mathrm{H}$

Received : 25.08.2014

Revised : 05.05.2015

Accepted : 29.05.2015

Members of the Research Forum

Associated Authors:

${ }^{1}$ Department of Agronomy,

Sardar Vallabhbhai Patel University

of Agriculture and Technology,

MEERUT (U.P.) INDIA

${ }^{2}$ Department of Horticulture, C.C.R. P.G. College, MUZAFFARNAGAR

(U.P.) INDIA

${ }^{3}$ Directorate of Floriculture

Research, ICAR, NEW DELHI, INDIA

Author for correspondence :

SATYA PRAKASH

Krishi Vigyan Kendra,

SAHARANPUR (U.P.) INDIA
THE ASIAN JOURNAL OF HORTICULTURE

Volume 10 | Issue 1 | June, 2015 | 149-152

Visit us -www.researchjournal.co.in

RESEARCH PAPER

DOI : 10.15740/HAS/TAJH/10.1/149-152

\title{
Varietal performance of tuberose in Muzaffarnagar under western plain zone condition
}

\section{SATYA PRAKASH, J.K. ARYA ${ }^{1}$, R.K. SINGH ${ }^{2}$ AND K.P. SINGH ${ }^{3}$}

ABSTRACT : A field experiment was conducted on the varietal performance of tuberose in Muzaffarnagar Under Western Plain Zone condition at Krishi Vigyan Kendra campus and farmers field in 2013 and 2014. The experiment was jointly organised with Directorate of Floriculture Research Institute, I.C.A.R., New Delhi. The study revealed that the Prajwal variety perform batter in comparison to other variety. Prajwal variety highest length of spike $(111 \mathrm{~cm})$, rachis length $(31.53 \mathrm{~cm})$, number of Florate $(60.33)$ and diametre of spike $(12.92 \mathrm{~mm})$ and minimum rachis length $(20.22 \mathrm{~cm})$ number of Florates $(40.40)$ and diametre of spike $(3.70 \mathrm{~mm})$ in Mexican single. Which was significantly lower in comparison to variety Prajwal?

KEY WORDS : Tuberose, Varietal performance, Varieties, Spikes, Clumb

HOW TO CITE THIS ARTICLE : Prakash, Satya, Arya, J.K., Singh, R.K. and Singh, K.P. (2015). Varietal performance of tuberose in Muzaffarnagar under western plain zone condition. Asian J. Hort., 10(1) : 149-152. 